\title{
Alterations in serum lipids and apolipoproteins in male Type 1 (insulin-dependent) diabetic patients with microalbuminuria
}

\author{
R.P.F.Dullaart ${ }^{1}$, L.D. Dikkeschei ${ }^{2}$ and H. Doorenbos ${ }^{1}$ \\ ${ }^{1}$ Departments of Endocrinology and ${ }^{2}$ Clinical Chemistry, University Hospital Groningen, Groningen, The Netherlands
}

\begin{abstract}
Summary. The relationships between serum lipid, apolipoprotein levels and urinary albumin excretion were investigated in 20 male Type 1 (insulin-dependent) diabetic patients with microalbuminuria (overnight urinary albumin excretion between 10 and $200 \mu \mathrm{g} / \mathrm{min}$ ), in 18 male Type 1 diabetic patients without microalbuminuria and in 18 male control subjects. In the microalbuminuric patients low density lipoprotein cholesterol was higher than in the control subjects $(p<0.05)$; the high density lipoprotein/low density lipoprotein cholesterol ratio was lower than in the normoalbuminuric diabetic patients $(p<0.05)$, and in the control subjects $(p<0.01)$; apolipoprotein $B$ was higher than in the normoalbuminuric patients $(p<0.05)$; the apolipoprotein $\mathrm{A}_{1} / \mathrm{B}$ ratio was lower than in the normoalbuminuric diabetic patients $(p<0.05)$. Serum triglyceride was higher in the microalbuminuric diabetic patients and in the control subjects than in the normoalbuminuric diabetic patients ( $p<0.05$, for both), but was not different be-
\end{abstract}

tween the microalbuminuric diabetic patients and the control subjects. No significant differences between the 3 groups were present with respect to serum cholesterol, high density lipoprotein cholesterol and apolipoprotein $\mathrm{A}_{1}$. In the 2 combined Type 1 diabetic groups there were significant correlations between urinary albumin excretion and the high density lipoprotein/low density lipoprotein cholesterol ratio $(\mathrm{R}-0.40$, $p<0.02)$, apolipoprotein $\mathrm{B}(\mathrm{R} 0.35, p<0.05)$ and the apolipoprotein $\mathrm{A}_{1} / \mathrm{B}$ ratio $(\mathrm{R}-0.44, p<0.01)$. These results indicate microalbuminuria related differences in lipid and apolipoprotein levels in male Type 1 diabetic patients, which may contribute to an increased risk of cardiovascular disease.

Key words: Lipoproteins, apolipoproteins, microalbuminuria, incipient nephropathy, Type 1 (insulin-dependent) diabetes mellitus.
Cardiovascular disease is the major cause of premature death in Type 1 (insulin-dependent) diabetes mellitus [1-3]. Diabetic patients are also at risk from the cardiovascular risk factors such as smoking, hypertension and serum lipid levels. Epidemiological studies have shown that the excess risk for cardiovascular mortality is observed predominantly in those patients, who have developed diabetic nephropathy [4,5]. Indeed, a higher prevalence of the risk factors of smoking and elevated blood-pressure appears to be present in patients with proteinuria [6-10]. Many reports have shown unaltered or increased levels of HDL cholesterol, normal LDL cholesterol levels and normal or low apolipoprotein B (apo B) levels in Type 1 diabetes, provided metabolic control is adequate and kidney function is well preserved [11-18]. In contrast, the presence of diabetic nephropathy and possibly also retinopathy is associated with lipoprotein abnormalities which harbour an increased risk for cardiovascular disease $[9,10,19-22]$. Diabetic nephropathy, hallmarked by persistent proteinuria, is preceded by a phase of incipient nephropathy, which is characterised by microalbuminuria [23-25].

The present study was conducted to investigate possible alterations in lipid and apolipoprotein levels in Type 1 diabetic patients with early renal lesions as indicated by microalbuminuria.

\section{Subjects and methods}

All subjects consented to the procedure after explanation of the purpose of the study, which was approved by the local medical ethics committee. Three groups of subjects were investigated (Table 1).

a) 20 Type 1 diabetic patients with microalbuminuria (urinary albumin excretion rate (Ualb.V) ranging from 10 to $200 \mu \mathrm{g} / \mathrm{min}$ ): D Micro.

b) 18 Type 1 diabetic patients with normal Ualb.V (less than $10 \mu \mathrm{g} / \mathrm{min}$ ): D Normo.

c) 18 control subjects (Ualb. V less than $10 \mu \mathrm{g} / \mathrm{min}$ ): C.

The level of Ualb. V was determined in 3 consecutive overnight urine collections obtained within 3 months prior to the study. Three urine 
Table 1. Clinical characteristics of the 3 groups of diabetic and nondiabetic subjects

\begin{tabular}{|c|c|c|c|}
\hline & $\begin{array}{l}\text { D Micro } \\
(n=20)^{\mathrm{a}}\end{array}$ & $\begin{array}{l}\text { D Normo } \\
(n=18)^{\mathrm{a}}\end{array}$ & $\begin{array}{l}\mathrm{C} \\
(n=18)^{\mathrm{a}}\end{array}$ \\
\hline Age (years) & $46(21-60)$ & $43(22-69)$ & $41(21-63)$ \\
\hline $\begin{array}{l}\text { Duration of diabetes } \\
\text { (years) }\end{array}$ & $18(6-40)$ & $18(2-41)$ & - \\
\hline Ualb.V $(\mu \mathrm{g} / \mathrm{min})$ & $29(10-228)$ & $3(1-9)^{e}$ & $3(1-6)^{e}$ \\
\hline $\begin{array}{l}\text { Serum creatinine } \\
\quad(\mu \mathrm{mol} / \mathrm{l})\end{array}$ & $85 \pm 14$ & $82 \pm 11^{c}$ & $87 \pm 6$ \\
\hline $\begin{array}{l}\text { Overnight creatinine } \\
\text { clearance } \\
\left(\mathrm{ml} \cdot \mathrm{min}^{-1}\right. \\
\left.1.73 \mathrm{~m}^{2-1}\right)\end{array}$ & $102 \pm 24$ & $109 \pm 20$ & $105 \pm 20$ \\
\hline $\begin{array}{l}\text { Glomerular filtration } \\
\text { rate }\left(\mathrm{ml} \cdot \min ^{-1} \text {. }\right. \\
\left.1.73 \mathrm{~m}^{2-1}\right)\end{array}$ & $128 \pm 31$ & n.d. & n.d. \\
\hline $\begin{array}{l}\text { Body mass index } \\
\left(\mathrm{kg} / \mathrm{m}^{2}\right)\end{array}$ & $24.23 \pm 2.33$ & $24.00 \pm 1.84$ & $22.83 \pm 2.07$ \\
\hline $\begin{array}{l}\text { Insulin dose } \\
\quad\left(\mathrm{U} \cdot \mathrm{kg}^{-1} \cdot \mathrm{day}^{-1}\right)\end{array}$ & $0.78 \pm 0.24$ & $0.70 \pm 0.18$ & - \\
\hline Smokers (n) & 11 & 7 & 4 \\
\hline $\mathrm{HbA}_{1}(\%)$ & $8.23 \pm 1.17^{\mathrm{d}}$ & $7.55 \pm 1.24^{\mathrm{d}}$ & $5.46 \pm 0.67$ \\
\hline $\begin{array}{l}\text { Fasting blood glucose } \\
\quad(\mathrm{mmol} / \mathrm{l})\end{array}$ & $12.44 \pm 3.00^{\mathrm{d}}$ & $10.73 \pm 4.22^{\mathrm{d}}$ & $4.50 \pm 0.37$ \\
\hline Serum albumin $(\mathrm{g} / \mathrm{l})$ & $43.35 \pm 2.37^{\mathrm{c}}$ & $43.61 \pm 2.38^{\mathrm{c}}$ & $45.28 \pm 2.40$ \\
\hline $\begin{array}{l}\text { Mean blood pressure } \\
\quad(\mathrm{mm} \mathrm{Hg})\end{array}$ & $95 \pm 8$ & $94 \pm 8$ & $95 \pm 6$ \\
\hline Retinopathy $(\mathrm{O} / \mathrm{B} / \mathrm{P})^{\mathrm{b}}$ & $4 / 10 / 6$ & $9 / 8 / 1$ & - \\
\hline
\end{tabular}

a D Micro: Type 1 (insulin-dependent) diabetic patients with microalbuminuria; D Normo: Type 1 diabetic patients without microalbuminuria; $C$ : Control subjects

b Retinopathy: O: absent; B: background; P: proliferative.

Results are given as mean $\pm \mathrm{SD}$ or median (range) as indicated

${ }^{c}$ denotes $p<0.05$ from $\mathrm{C}$; ${ }^{\mathrm{d}}$ denotes $p<0.01$ from $\mathrm{C}$; ${ }^{\mathrm{e}}$ denotes $p<0.01$ from D Micro

collections were used for classifying patients because of the high coefficient of variation of Ualb.V (of about 45\%) [26]. A level of $10 \mu \mathrm{g} / \mathrm{min}$ represents the upper normal limit of Ualb. V in our clinic. Levels persistently above $200 \mu \mathrm{g} / \mathrm{min}$, corresponding with a urinary protein excretion above $500 \mathrm{mg} / 24 \mathrm{~h}$, indicate diabetic nephropathy. Urinary tract infection was excluded by bacterial culture. Serum creatinine was below $120 \mu \mathrm{mol} / 1$ in all subjects. Between the 3 groups no differences in creatinine clearance determined in overnight urine collections could be demonstrated. The glomerular filtration rate, measured with ${ }^{125}$ I-iothalamate [27] was determined only in D Micro and was above $85 \mathrm{ml} \cdot \mathrm{min}^{-1} \cdot 1.73 \mathrm{~m}^{2-1}$ in all tested subjects.

The Type 1 diabetic patients were recruited from the outpatient clinic and, by the use of multiple daily insulin injections, were in a metabolically stable condition. All the patients suffered from ketosis prone diabetes mellitus and were deemed insulin-dependent on clinical grounds. The control subjects were recruited from hospital personnel. No subject had arterial hypertension (systolic bloodpressure $>160 \mathrm{~mm} \mathrm{Hg}$, diastolic blood pressure (Korotkoff phase 5) $>90 \mathrm{~mm} \mathrm{Hg}$ ). Only male subjects were recruited thus avoiding any effect of the menstrual cycle [28] or the use of oral contraceptives on lipid levels. None of the subjects used any medication other than insulin known to affect lipoprotein levels or kidney function. No subject suffered from thyroid or liver disease as determined by routine thyroid and liver function tests.

As is shown in Table 1 , the 3 groups were closely matched for age and body mass index. The 2 Type 1 diabetic groups were matched for diabetes duration which was at least 2 years. The levels of Ualb.V, given in Table 1, are those from overnight collections obtained direct- ly before blood sampling. In $\mathrm{D}$ Micro all values were above $10 \mu \mathrm{g} / \mathrm{min}$, but one subject had Ualb.V above $200 \mu \mathrm{g} / \mathrm{min}$ $(228 \mu \mathrm{g} / \mathrm{min})$. There were no significant differences in metabolic control between D Micro and D Normo. On average metabolic control assessed by $\mathrm{HbA}_{1}$ was adequate. The mean fasting blood glucose values were higher than normal. There was no significant difference in insulin dose between the 2 diabetic groups. Retinopathy tended to be more severe in D micro $(0.05<p<0.10)$. In D Micro more smokers were present, but the prevalence of smoking was not significantly different between the 3 groups $(p>0.20)$. Three patients from D Micro and 1 patient from $D$ Normo had suffered from a myocardial infarction (at least 6 months previous to the study). One patient from $D$ Normo was suffering from ischaemic cerebrovascular disease. No one in $\mathrm{C}$ had cardiovascular disease.

\section{Laboratory methods}

Venous blood was drawn after a $12 \mathrm{~h}$ fast. The last administration of insulin was $12 \mathrm{~h}$ before blood sampling. Blood used for lipid and apolipoprotein determinations was allowed to clot. Serum was separated at $3000 \mathrm{rev} / \mathrm{min}$ for $12 \mathrm{~min}$ within $1-2 \mathrm{~h}$. Samples were frozen at $-20^{\circ} \mathrm{C}$ and assayed within 4 weeks. The assays were performed in duplicate in one run.

\section{Lipid assays}

Lipids were measured in serum and the HDL containing supernatant after precipitation of apo B containing lipoproteins with sodium phosphotungstate and $\mathrm{MgCl}_{2}$ [29]. Cholesterol and triglyceride were measured enzymatically using automated methods [30,31]. LDL cholesterol was calculated by the Friedewald formula [32]. Apolipoprotein $A_{1}\left(\right.$ apo $A_{1}$ ) and $B$ were determined by immunoturbidimetry on a Multistat I centrifugal analyser (Instrumentation Laboratories, - Ijsselstein, The Netherlands) using commercially available kits (Boehringer, Mannhiem, FRG, cat. no. 726478 and 726494, respectively). Coefficient of variation 5.2 and $4.6 \%$, respectively.

\section{Other techniques}

Urinary albumin was measured by a commercially available double antibody radioimmunoassay (Diagnostic Products Corporation, Apeldoorn, The Netherlands, cat. no. $\mathrm{KHAD}_{2}$ ). Serum and urinary creatinine were measured on a SMAC II autoanalyser (Technicon Instruments Inc., TarryTown, NY, USA). $\mathrm{HbA}_{1}$ was determined by colorimetry [33]. Glucose was measured on a Yellow Springs glucose analyser (YSI Model 23A, Yellow Springs Inc., Yellow Springs, Ohio, USA).

\section{Statistical analysis}

Results are expressed as mean \pm SD for normally distributed data and as median and range for non-parametrically distributed data. $p$ values less than 0.05 were considered to be significant. Differences in prevalence of variables among groups were analysed by chi-square analysis [34]. Comparison of data among groups was performed by analysis of variance for parametrically and non-parametrically distributed data as appropriate. Adjustment for multiple comparisons was carried out using Duncan's method [35]. Spearman's rank correlation coefficients were used for the assessment of relationships between variables for the combined 2 groups of Type 1 diabetic patients [34]. Subsequently multiple stepwise linear regression analysis was carried out to evaluate the independence of relationships. In this analysis $\log _{10}$ transformed Ualb. V values were used. 


\section{Results}

The serum concentrations of lipids and apolipoproteins are given in Table 2. Between the 3 groups there were no significant differences in serum cholesterol levels. Serum triglyceride was slightly lower in D Normo $(p<0.05)$ than in D Micro and in C. No differences between $\mathrm{D}$ Micro and $\mathrm{C}$ were found. HDL cholesterol was not significantly different in the 3 groups. LDL cholesterol levels were higher in D Micro than in $\mathrm{C}$ $(p<0.05)$.

The HDL/LDL cholesterol ratio was lower in D Micro than in D Normo $(p<0.05)$ and in C $(p<0.01)$. No differences in apo $A_{1}$ levels could be demonstrated. Apo B was higher in D Micro than in D Normo $(p<0.05)$. The difference between $\mathrm{D}$ Micro and $\mathrm{C}$ was close to statistical significance $(0.05<p<0.10)$. The apo $\mathrm{A}_{1}$ /apo $\mathrm{B}$ ratio was lower in $\mathrm{D}$ Micro than in D Normo $(p<0.05)$. The serum concentrations of lipids and apolipoproteins were also compared in the nonsmokers and smokers from the 3 groups separately. Among the non-smokers the HDL/LDL cholesterol ratio was lower in D Micro $(0.32 \pm 0.10)$ than in $\mathrm{C}$ $(0.39 \pm 0.11, p<0.05)$. Among the smokers the apo $A_{1}$ /apo $B$ ratio was lower in D Micro $(1.28 \pm 0.38)$ than in D Normo $(1.59 \pm 0.28, p<0.05)$. In D Micro LDL cholesterol and apo B tended to be higher both in the non-smokers and smokers, but the differences were not significant in these small groups of subjects.

The correlation coefficients between Ualb.V and the various lipid parameters in the combined 2 groups of Type 1 diabetic patients are given in Table 3 . The Ualb. $V$ values used are those from one overnight collection obtained directly before lipid determinations. There was a positive correlation between Ualb. $V$ and apo $\mathrm{B}(p<0.05)$ and there were negative correlations between Ualb. V and the HDL/LDL cholesterol ratio $(p<0.02)$ and the apo $\mathrm{A}_{1} /$ apo $\mathrm{B}$ ratio $(p<0.01)$. Multiple linear regression analysis was performed to determine the independence of these relationships. It could be demonstrated that the relationships of Ualb. V and apo B, HDL/LDL cholesterol ratio, apo $\mathrm{A}_{1} /$ apo $\mathrm{B}$ ratio were independent. These relationships were not attributable to other clinical parameters including the number of cigarettes smoked daily, age, diabetes duration, body mass index, insulin dose, $\mathrm{HbA}_{1}$, blood glucose and degree of retinopathy. No significant correlations could be demonstrated of Ualb. $V$ and serum cholesterol, serum triglyceride, LDL cholesterol and apo $A_{1}$. The inverse correlation with HDL cholesterol was close to statistical significance $(0.05<p<0.10)$. Furthermore, there was a positive correlation between Ualb. $V$ and the degree of retinopathy $(\mathrm{R} 0.32, p<0.05)$. The independence of this relationship was confirmed by multiple linear regression analysis. There was also a negative correlation between the degree of retinopathy and the apo $\mathrm{A}_{1} /$ apo $\mathrm{B}$ ratio $(\mathrm{R}-0.34, p<0.05)$. This relationship, however,
Table 2. Serum concentrations of lipids and apolipoproteins in the 3 groups

\begin{tabular}{llll}
\hline & D Micro $^{\mathrm{a}}$ & D Normo $^{\mathrm{a}}$ & $\mathrm{C}^{\mathrm{a}}$ \\
\hline $\begin{array}{c}\text { Cholesterol } \\
(\mathrm{mmol} / \mathrm{l})\end{array}$ & $6.01 \pm 1.19$ & $5.51 \pm 0.79$ & $5.40 \pm 0.96$ \\
$\begin{array}{c}\text { Triglyceride } \\
(\mathrm{mmol} / \mathrm{l})\end{array}$ & 0.92 & 0.79 & 1.07 \\
$\begin{array}{c}\mathrm{HDL} \text { cholesterol } \\
(\mathrm{mmol} / \mathrm{l})\end{array}$ & $(0.35-2.80)$ & $(0.47-2.56)^{\mathrm{b}, \mathrm{d}}$ & $(0.51-2.03)$ \\
$\begin{array}{c}\text { LDL cholesterol } \\
(\mathrm{mmol} / \mathrm{l})\end{array}$ & $1.15 \pm 0.34$ & $1.27 \pm 0.19$ & $1.27 \pm 0.19$ \\
$\begin{array}{c}\mathrm{HDL} / \mathrm{LDL} \\
\text { cholesterol }\end{array}$ & $0.29 \pm 0.12^{\mathrm{c}}$ & $0.34 \pm 0.06^{\mathrm{d}}$ & $0.37 \pm 0.11$ \\
$\begin{array}{c}\text { Apolipo- } \\
\text { protein } \mathrm{A}_{1}(\mathrm{~g} / \mathrm{l})\end{array}$ & $1.28 \pm 0.24$ & $1.24 \pm 0.15$ & $1.28 \pm 0.15$ \\
$\begin{array}{c}\text { Apolipo- } \\
\text { protein B }(\mathrm{g} / 1)\end{array}$ & $0.97 \pm 0.28$ & $0.79 \pm 0.17^{\mathrm{d}}$ & $0.83 \pm 0.17$ \\
$\begin{array}{c}\text { Apolipo- } \\
\text { protein } \mathrm{A}_{1} / \mathrm{B}\end{array}$ & $1.41 \pm 0.47$ & $1.70 \pm 0.44^{\mathrm{d}}$ & $1.57 \pm 0.37$ \\
\hline
\end{tabular}

a D Micro, D Normo and C: for explanation see Table 1

b denotes $p<0.05$ from $C$; ${ }^{c}$ denotes $p<0.01$ from $C$; d denotes $p<0.05$ from D Micro

Table 3. Correlation coefficients between urinary albumin excretion rate and serum lipid parameter in the 2 combined groups of 38 Type 1 (insulin-dependent) diabetic patients

\begin{tabular}{lc} 
& Urinary albumin excretion rate \\
\hline Cholesterol & 0.13 \\
HDL cholesterol & -0.28 \\
LDL cholesterol & 0.12 \\
HDL/LDL cholesterol & $-0.40^{\mathrm{b}}$ \\
Triglyceride & 0.24 \\
Apolipoprotein $\mathrm{A}_{1}$ & -0.12 \\
Apolipoprotein $\mathrm{B}$ & $0.35^{\mathrm{a}}$ \\
Apolipoprotein $\mathrm{A}_{1} / \mathrm{B}$ & $-0.44^{\mathrm{c}}$ \\
\hline a denotes $p<0.05$; $^{\mathrm{b}}$ denotes $p<0.02$; $^{\mathrm{c}}$ denotes $p<0.01$ \\
Spearman rank correlation coefficients are given
\end{tabular}

disappeared in multiple linear regression analysis and could be attributed to the correlation between Ualb. V and the apo $\mathrm{A}_{1}$ /apo $\mathrm{B}$ ratio.

\section{Discussion}

The present cross sectional study demonstrates alterations in lipid and apolipoprotein profiles in Type 1 diabetes with renal lesions as early as incipient nephropathy. In association with microalbuminuria higher LDL cholesterol and apo B concentrations and lower $\mathrm{HDL} / \mathrm{LDL}$ cholesterol and apo $\mathrm{A}_{1}$ /apo $\mathrm{B}$ ratios were observed. These differences in lipid and apolipoprotein levels are related to an increased risk of cardiovascular disease [36, 37]. Lower HDL/LDL cholesterol and apo $A_{1}$ /apo $B$ ratios in the microalbuminuric patients were also demonstrable when the non-smokers and smokers were analysed separately. This indicates that the alterations in lipids and apolipoproteins in the microalbuminuric patients were not merely attributable 
to smoking which is known to be related to microvascular diabetic complications and unfavourable lipid profiles $[6,7,38]$. Furthermore, in the combined 2 Type 1 diabetic groups independent relationships between urinary albumin excretion and apolipoprotein B, $\mathrm{HDL} / \mathrm{LDL}$ cholesterol, apo $\mathrm{A}_{1}$ /apo $\mathrm{B}$ were found. No significant differences in serum cholesterol could be measured. Serum triglyceride was slightly higher in the microalbuminuric and the control group than in the normo-albuminuric group. There was no relationship between urinary albumin excretion and serum triglyceride.

Previous studies have shown lipoprotein abnormalities in diabetic nephropathy $[10,19,21,22]$. In incipient nephropathy no significant differences in HDL, LDL, and VLDL cholesterol and an increase in apo B have been reported $[21,22]$. In that study no correlation between urinary albumin excretion and apo B could be demonstrated [21]. While the present study was under consideration, two reports have appeared also showing alterations in lipids and apolipoproteins in microalbuminuria $[39,40]$. In our study the overnight urinary albumin excretion rate, considered to be abnormal (above $10 \mu \mathrm{g} / \mathrm{min}$ ), was low. Lipoprotein abnormalities may, therefore, be present even when the urinary albumin excretion rate is only slightly increased. A relationship between retinopathy and lipid levels has been observed $[19,20]$. In the present study a negative correlation between the degree of retinopathy and apo $\mathrm{A}_{1}$ /apo $\mathrm{B}$ ratio was found, but this relationship disappeared upon correction for urinary albumin excretion.

The mechanisms behind the alterations in lipids and apolipoprotein levels found in microalbuminuria and proteinuria remain to be elucidated. In the nephrotic syndrome an increased hepatic lipoprotein synthesis as well as an impaired catabolism has been documented $[41,42]$. Leakage in the urine of HDL has been reported in nephrotic rats and non-diabetic nephrotic man [42-44] and may contribute to a low HDL/LDL cholesterol ratio. Serum levels of lipoproteins are, at least in part, genetically determined among other factors through apo $B$ and apo E polymorphism and inherited differences in LDL subclasses [45-47]. These possibilities have not yet been investigated.

When studies from non-diabetic populations, showing a $2 \%$ decrease in cardiovascular death per $\%$ decrease in serum cholesterol [48] are extrapolated to the diabetic population, it is clear that differences in lipid levels of the magnitude presently demonstrated for microalbuminuria do not explain the highly increased cardiovascular mortality in patients who have developed diabetic nephropathy. Such an assumption may not be valid however. In vitro studies have shown that extravasated lipoproteins may be trapped in the arterial wall to a greater extent in diabetes due to increased cross linking with advanced glycosylation end products on extra cellular matrix proteins [49]. Macrophages accumulate more cholesterylester when exposed to glycosylated LDL in vitro [50]. These mechanisms would lead to a decrease of cholesterylester outflux from the arterial wall and would promote atherogenesis. In diabetes, complicated by microalbuminuria, outflux from plasma of proteins, especially albumin, is increased [51]. A concomitant increase in the outflux of other macromolecules might thus promote atherogenesis particularly in patients with renal lesions $[50,52]$. It seems possible, therefore, that the cardiovascular risk associated with a small increase in lipid levels is higher for diabetic patients with renal lesions than for diabetic patients without renal lesions and for normal subjects. It appears to be of major clinical interest to decrease lipid levels in diabetic patients with microalbuminuria, not only to retard atherosclerotic manifestations, but also to attenuate possible detrimental effects of high lipid levels on renal function [53].

Acknowledgements. This study was supported by a grant from the Dutch Diabetes Research Fund. M. Volmer performed the multiple regression analysis.

\section{References}

1. Kessler II (1971) Mortality experience of diabetic patients. A twenty-six year follow-up study. Am J Med 51: 715-724

2. Kannel WB, McGee DL (1979) Diabetes and cardiovascualr disease. The Framingham study. JAMA 241: 2035-2038

3. Green A, Hougaard P (1984) Epidemiological studies of diabetes mellitus in Denmark: 5.Mortality and causes of death among insulin treated-diabetic patients. Diabetologia 26: 190-194

4. Borch-Johnsen K, Andersen PK, Deckert T (1985) The effect of proteinuria on relative mortality in Type 1 (insulin-dependent) diabetes mellitus. Diabetologia 28: 590-596

5. Borch-Johnsen K, Kreiner S (1987) Proteinuria: value as predictor of cardiovascular mortality in insulin-dependent diabetes mellitus. Br Med J 294: 1651-1654

6. Christiansen JS (1978) Cigarette smoking and prevalence of microangiopathy in juvenile onset insulin-dependent diabetes mellitus. Diabetes Care 1: 146-149

7. Telmer S, Christiansen JS, Andersen AR, Nerup J, Deckert T (1984) Smoking habits and prevalence of clinical diabetic microangiopathy in insulin-dependent diabetics. Acta Med Scand 215: 63-68

8. Parving HH, Andersen AR, Smidt UM, Oxenbøll B, Edsberg B, Christiansen JS (1983) Diabetic nephropathy and arterial hypertension. Diabetologia 24: 10-12

9. Jensen T, Borch-Johnsen K, Kofoed-Enevoldsen A, Deckert T (1987) Coronary heart disease in young Type 1 (insulin-dependent) diabetic patients with and without diabetic nephropathy: incidence and risk factors. Diabetologia 30: 144-148

10. Winocour PH, Durrington PN, Ishola M, Anderson DC, Cohen $\mathrm{H}$ (1987) Influence of proteinuria on vascular disease, blood pressure, and lipoproteins in insulin dependent diabetes mellitus. $\mathrm{Br}$ Med J 294: 1648-1651

11. Sosenko JM, Breslow JL, Miettinen OS, Gabbay KH (1980) Hyperglycemia and plasma lipid levels. A prospective study of young insulin-dependent diabetic patients. N Eng J Med 302: 650-654

12. Durrington PN (1980) Serum high density lipoprotein cholesterol in diabetes mellitus: an analysis of factors which influence its concentration. Clin Chim Acta 104: 11-23

13. Eckel RH, Albers JJ, Cheung MC, Wahl PW, Lindgren FT, Bierman EL (1981) High density lipoprotein composition in insulin dependent diabetes mellitus. Diabetes 30: 132-138 
14. Lopes-Virella MF, Wohltmann HJ, Loadholt CB, Buse MG (1981) Plasma lipids and lipoproteins in young insulin-dependent diabetic patients: Relationship with control. Diabetologia 21: 216-223

15. Laakso M, Voutilainen E, Sarlund H, Aro A, Pyörälä K, Penttila I (1985) Inverse relationship of serum $\mathrm{HDL}$ and $\mathrm{HDL}_{2}$ cholesterol to c-peptide level in middle-aged insulin-treated diabetics. Metabolism 34: 715-720

16. Winocour PH, Durrington DN, Ishola M, Anderson DC (1986) Lipoprotein abnormalities in insulin-dependent diabetes mellitus. Lancet I: $1176-1178$

17. Weisweiler P, Schwandt P (1987) Type 1 (insulin-dependent) versus Type 2 (non-insulin dependent) diabetes mellitus: characterization of serum lipoprotein alterations. Eur J Clin Invest 17:87-91

18. Laakso M, Sarlund H, Ehnholm C, Voutilainen E, Aro A, Pyörälä K (1987) Relationship between postheparin plasma lipases and high-density lipoprotein cholesterol in different types of diabetes. Diabetologia 30: 703-706

19. Eckel RH, McLean E, Albers JJ, Cheung MC, Bierman EL (1981) Plasma lipids and microangiopathy in insulin-dependent diabetes mellitus. Diabetes Care 4: 447-453

20. Dornan TL, Carter RD, Bron AJ, Turner RC, Mann JI (1982) Low density lipoprotein cholesterol: an association with the severity of diabetic retinopathy. Diabetologia 22: 167-170

21. Vannini P, Ciavarella A, Flammini M, Bargossi AM, Forlani G, Borgnino LC, Orsoni G (1984) Lipid abnormalities in insulindependent diabetic patients with albuminuria. Diabetes Care 7: 151-154

22. Jensen T, Stender S, Deckert T (1988) Abnormalities in plasma concentrations of lipoproteins and fibrinogen in Type 1 (insulindependent) diabetic patients with increased urinary albumin excretion. Diabetologia 31: 142-145

23. Viberti GC, Jarret RJ, Mahmud U, Hill RD, Argyropoulos A, Keen $H$ (1982) Microalbuminuria as a predictor of clinical nephropathy in insulin dependent diabetes mellitus. Lancet I: $1430-1432$

24. Mogensen CE, Christensen CK, Vittinghus E (1983) The stages in diabetic renal disease with emphasis on the stage of incipient diabetic nephropathy. Diabetes 32 [Suppl 2]: 64-78

25. Mogensen CE, Christensen CK (1984) Predicting diabetic nephropathy in insulin-dependent patients. N Engl J Med 311: 89-93

26. Mogensen CE (1971) Urinary albumin excretion in early and longterm juvenile diabetes. Scand J Clin Lab Invest 28: 183-193

27. Donker AJM, van der Hem GK, Sluiter WJ, Beekhuis H (1977) A radioisotope method for simultaneous determination of the glomerular filtration rate and the effective renal plasma flow. Neth J Med 20: 97-103

28. Jones DY, Judd JT, Taylor PR, Campbell WS, Nair PP (1988) Menstrual cycle effect on plasma lipids. Metabolism 37:1-2

29. Lopes-Virella MF, Stone P, Ellis S, Colwell JA (1977) Cholesterol determinations in high density lipoproteins separated by three different methods. Clin Chem 23: 882-884

30. Lie RF, Schmitz JM, Pierre KJ, Gochman N (1976) Cholesterol oxidase based determination by continuous flow analysis of total and free cholesterol in serum. Clin Chem 22:1627-1630

31. Bucolo G, David H (1973) Quantitative determination of serum triglycerides by use of enzymes. Clin Chem 19:475-482

32. Friedewald WT, Levy RI, Fredrickson DS (1972) Estimation of the concentration of low-density lipoprotein cholesterol in plasma, without use of the preparative ultracentrifuge. Clin Chem 18: 499-502

33. Flückiger R, Winterthalter KH (1976) In vitro synthesis of hemoglobin Alc. FEBS Letters 71: 356-360

34. Diem K (1980) Wissenschaftliche Tabellen Geigy 8th edition. Ciba Geigy, Basel, Switzerland

35. Duncan DB (1955) Multiple range and multiple F-tests. Biometrics 11: $1-42$

36. Avogaro P, Cazzolato G, Bittolo Bon G, Quinci GB (1979) Are apolipoproteins better discriminators than lipids for atherosclerosis? Lancet I: 901-903
37. Ball M, Mann JI (1986) Apoproteins: predictors for coronary heart disease? Br Med J 293: 769-770

38. Craig WY, Palomaki GE, Haddow JE (1989) Cigarette smoking and serum lipid and lipoprotein concentrations: an analysis of published data. Br Med J 298: 784-788

39. Watts GF, Naumova R, Slavin BM, Morris RW, Houlston R, Kubal C, Shaw KM (1989) Serum lipids and lipoproteins in insulin-dependent diabetic patients with persistent microalbuminuria. Diabetic Med 6: 25-30

40. Jones SL, Close CF, Mattock MB, Jarrett RJ, Keen H, Viberti GC (1989) Plasma lipid and coagulation factor concentrations in insulin-dependent diabetics with microalbuminuria. Br Med J 298: 487-490

41. Marsh JB, Drabkin DK (1960) Experimental reconstruction of metabolic patterns of lipid nephrosis: Key role of hepatic protein synthesis in hyperlipidemia. Metabolism 9:946-955

42. Gitlin D, Cornwall DG, Nakasoto D, Oncley JL, Hughes WL Jr, Janeway CA (1958) Studies on the metabolism of plasma proteins in the nephrotic syndrome II. The lipoproteins. J Clin Invest 37 : $172-184$

43. de Mendoza SG, Kashyap ML, Chen CY, Lutmer RF (1976) High density lipoproteinuria in nephrotic syndrome. Metabolism 26: 1143-1149

44. Kashyap ML, Ooi BS, Hynd BA (1979) Sequestration and excretion of high density lipoproteins by the kidney in human nephrotic syndrome. Artery 6: 108-121

45. Tikkanen MJ, Viikari J, Ảkerblom HK, Pesonen E (1988) Apolipoprotein B polymorphism and altered apolipoprotein B and low density lipoprotein cholesterol concentration in Finnish children. Br Med J 296: 169-170

46. Eto M, Watanake K, Iwashima Y, Morikawa A, Oshima E, Sekiguchi M, Ishii K (1986) Apolipoprotein E polymorphism and hyperlipidemia in Type II diabetics. Diabetes 35: 1374-1382

47. Austin MA, Krauss RM (1986) Genetic control of low density lipoprotein subclasses. Lancet II: 592-595

48. Lipid Research Clinics Program (1984) The Lipid Research Clinics Coronary Primary Prevention Trial Results. JAMA 251: 351-374

49. Brownlee M, Cerami A, Vlassara H (1988) Advanced glycosylation end products in tissue and the biochemical basis of diabetic complications. N Eng J Med 318: 1315-1321

50. Lyons TJ, Klein RL, Baynes JW, Stevenson HC, Lopes-Virella MF (1987) Stimulation of cholesteryl ester synthesis in human monocyte-derived macrophages by low-density lipoproteins from Type 1 (insulin-dependent) diabetic patients: the influence of non-enzymatic glycosylation of low density lipoproteins. Diabetologia 30: 916-923

51. Feldt-Rasmussen B (1986) Increased transcapillary escape rate of albumin in Type 1 (insulin-dependent) diabetic patients with microalbuminuria. Diabetologia 29: 282-286

52. Ross R (1986) The pathogenesis of atherosclerosis: an update. $\mathrm{N}$ Eng J Med 314: 488-500

53. Moorhead JF, Chan MK, El-Nahas M, Varghese Z (1982) Lipid nephrotoxicity in chronic progressive glomerular and tubulo-interstitial disease. Lancet II: 1309-1311

Received: 1 November 1988

an in revised form: 12 May 1989

\section{Dr.R. P.F. Dullaart}

Department of Endocrinology

University Hospital Groningen

Oostersingel 59

NL-9713 EZ Groningen

The Netherlands 